\title{
Comparing And Managing The Relative Importance And Ranking Of Reasons For Selecting The Masters' Of Business Administration Program
}

\author{
Ronald L. Snyder, Southern Wesleyan University, USA \\ Lee E. Kizer, Southern Wesleyan University, USA \\ Bahaudin G. Mujtaba, Nova Southeastern University, USA \\ Nile M. Khanfar, Nova Southeastern University, USA
}

\begin{abstract}
This paper reports the findings of a study involving the selection process that adult graduate students used when choosing to pursue and attain an advanced business degree at Southern Wesleyan University. This study includes a comparison of the initial priorities used in the selection process to priorities that remain important in retrospect. The study also includes a comparison of the school's stated program objectives to the reasons for students' program selection. A two-tailed analysis of data supplied by 184 respondents revealed there was no significant difference between student responses at the beginning of the program and student responses at the conclusion of the program. The study also reveals a close alignment between the school's program objectives and some of the highest ranked priorities given by the students for choosing the programs. The four (4) highest ranked priorities at the beginning and at the end of the program included "Fits my schedule", "Job advancement/marketability", "Received undergraduate degree from SWU," and "Christian perspective." These results can assist University administrators, managers, and recruiters in adapting their marketing strategies to provide critical and relevant information to prospective students. The study did not consider demographics as a component of the selection process or with the school's stated program objectives.
\end{abstract}

Keywords: MBA program student selection process, Adult Graduate Students, Business program objectives, Marketing Strategies for MBA programs, Non-traditional MBA programs, Importance of ranking MBA programs, Considerations and constraints of selecting MBA programs.

\section{INTRODUCTION：HIGHER LEARNING INSTITUTIONS AND BUSINESS}

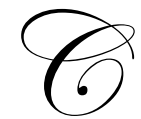

hoosing an institution of higher learning to earn an advanced business degree, i.e. Master of Business Administration (MBA), or Master of Science in Management (MSM) requires much research and deliberation. Prospective adult graduate students have numerous considerations and constraints including, but not limited to, family, finances and work. A decision of this magnitude could be one of the most important decisions these individuals make. As such, it becomes an integral part of a university's continuous improvement obligation to "put their fingers" on the pulse of their past, current and future students by regularly surveying them about their thoughts, needs and desires (Kenney and Mujtaba, 2008; Mujtaba, 2007A). Besides having a good reputation for academic quality and respected programs, students select a university and course of study that can actually enhance their performance outcome as students in the school and as individuals in the workplace (Mujtaba and McAtavey, 2006). This point is especially important for graduate students who are selecting a master's of business administration program. 
Some of the criteria for selection of an MBA Program may be common for many, but unique for others. The focus of this study centered on discovering if students had significantly different priorities in this critical advanced business degree selection process before beginning their program, as compared to priorities in retrospect. It was also important to determine if the University's stated program objectives closely aligned with the priorities for program selection.

Motivated by the desire to serve the adult population throughout the State of South Carolina and in a spirit open to innovative change, the Adult and Graduate Studies (AGS) program was developed at Southern Wesleyan University (SWU). SWU understands the special requirements of adults who are interested in receiving a graduate college business degree and have to continue to meet other personal commitments. The AGS program is designed for working adults, combining theory with practical experience.

The general objectives of the Southern Wesleyan University AGS Masters' programs (AGS Student Handbook, 2005) were:

1. Offer a program leading to a master's degree to people whose occupation, family responsibilities or personal preferences do not permit them to spend major blocks of time on a campus.

2. Provide a degree program that requires the mastery of learning outcomes at the academic level appropriate to students' degree goals.

3. Provide students with a comprehensive yet practical education through an intense curriculum that draws on resources, theories, and knowledge of all relevant disciplines in order to enable the students to acquire skills in communication, information processing, analysis, syntheses, and problem solving.

4. Facilitate an understanding of the importance of a dynamic social conscience and the application of Christian principles in a professional environment.

The data utilized in this study were obtained from the 2005 enrollment year for SWU's AGS program (Couch, 2005) and yielded the following demographic results: Population (313 students consisting of 140 males and 193 females with an average age of 39.3 years); race (161 White, 127 Black, 17 unknown, 5 Asian Pacific, 2 Native American/Alaskan, and 1 non-resident alien); and religious denomination (104 Baptists, 63 other, 55 nondenominational, 28 Catholics, 26 Methodists, 10 Presbyterians, 10 Lutherans, 5 Episcopalians, 7 Pentecostals and 5 Wesleyans).

This present study examines not only the importance and priorities of the reasons utilized in choosing an adult graduate program but also looks at whether or not these reasons remain constant throughout the students' program. The findings of this research will assist the University's administration in making future marketing and program development decisions.

\section{LITERATURE REVIEW OF COLLEGE TRANSITIONS}

The scope of our literature search encompassed high school graduates looking at undergraduate programs, working adults looking at part-time graduate MBA programs and adults seeking full-time MBA programs. Research initiatives looked at reasons for pursuing an MBA degree, the importance of selection criteria and overall influences in the selection process.

High School Graduates Matriculating into Undergraduate Business Programs. When high school students, their parents and others are in the process of selecting a college or university, many factors are considered (Mujtaba and McAtavey, 2006; Bowers and Pugh, 1973). According to their research, the two (2) most important reasons for students and their parents are academic reputation and the reputation of the specific department or school. While many other factors, such as geography, financial, social, cultural and living conditions, were points of discussion by both students and their parents, academics were at the top of the list. Important influences on college choice decisions from both student and parent perspectives (Broekemier and Seshadri, 1999) are also identified. Based on the research, the rank order of importance for high school students was: 1) Programs of study, 2) Cost advantages, 3) Availability of financial aid, 4) Job placement after graduation and 5) Facility quality. The rank order for parents was: 1) Programs of study, 2) Safety, 3) Cost advantages, 4) Academic reputation and 5) Facility quality. 
A study (Clinton, 1989) of high school graduates looking at colleges and universities reported the relative importance of decision criteria. The rank ordering was: 1) Recommendation of parents, 2) Degree programs in chosen career, 3) Quality education, and 4) Recommendations of friends. Other studies (Powers, 1988; Sevier, 1987 and Trusheim, Crouse \& Middaugh, 1990) about newly graduated high school students continuing their education as full-time undergraduates indicate a rank order as follows: 1) Academic reputation, 2) Quality of faculty, 3) Job opportunities and 4) Reputation of the faculty.

A research study (Broekemier, 2002) of adult/nontraditional (part-time, evening/weekend classes) undergraduate college students indicates the top ranked selection criterion is the program of study/majors and the second ranked criterion is the schedule for classes. Since religion is becoming an important factor in the workplace, some students and their parents are selecting education programs and institutions that are founded upon similar values as their own (Mujtaba, 2007B). Religion is perhaps just as important of selection criteria for undergraduate students as it is for graduate students. Therefore, institutions regularly conduct research to see if they are attracting and retaining students based on their values and whether their marketing efforts are fruitful.

College Graduates Matriculating into Nontraditional Graduate Business Programs. The benefits of pursuing an MBA degree differ between employees and their employers (Luker, Bowers and Powers, 1989). Working adults as part-time students list their top four (4) reasons for pursuing an MBA degree as: 1) Attain long-term career objectives, 2) Promotion possibilities, 3) Remain competitive in the job market and 4) Higher income.

The 1989 small survey of executives questioned the value of employees earning an MBA degree and their responses differed greatly from the perceptions of the adult part-time students (Luker, Bowers and Powers, 1989). For example, one of the questions asked, "Do you feel that pursuing an MBA degree can positively affect an employee's job performance?" The results were $40 \%$ responding YES and $60 \%$, NO.

Two articles (Kerr, 1995; Chui and Stembridge, 1999) cited working adults want to equip themselves for promotion and career development by enrolling in Executive type MBA programs. The study showed that Hong Kong students prefer part-time education over being full-time students because they don't want to lose out on business opportunities. The one study by Chui and Stembridge (1999) listed the top four (4) selection reasons in rank order as: 1) Institution's reputation, 2) Program curriculum 3) Tuition fees and 4) Mode of delivery.

Anecdotal information (Fieser, 2002) discusses the reasons for working adults returning to school on a parttime basis to pursue an MBA degree. In general, the author believes that a downturn in the economy, “...the economy has been so bad, but our aspirant roles are jumping...," stimulates interest in pursuing an MBA degree. Apparently, applicants want to improve their credentials and become more competitive for the existing job market. They are also searching for programs that are flexible in terms of hours and location.

Scheduling and flexibility become much more noted and rank quite a bit higher for nontraditional MBA students than for traditional undergraduate students. According to studies and one rank ordering, adult part-time students (Mujtaba, 2007A; Carrel, 2001) wanted: 1) New knowledge and perspectives gained, 2) Convenience of the program in terms of scheduling, 3) Prospect of increasing value/promotability and 4) Short duration of the program.

Research by Webb and Allen (1994), as well as Mujtaba (2007A, 2006), examined many different segments of graduate students, such as full-time vs. part-time, national vs. international and males vs. females. Backgrounds, cultures, race, aspirations, expectations, wants and needs of various groups are diverse and definitely influence students' matriculation decisions. Some of the results of the study for all part-timers were more influenced by the school's location, proximity and evening classes for their selection criteria. However, the female part-time students were significantly more influenced by the school's location, proximity, parking, academic/placement reputation, tuition and programs than their male counterparts.

It was reported (Oldham, 2000) that adult, working women needed to consider many personal criteria before choosing an MBA school. Some anecdotal stories about women deciding where to attend for earning an 
MBA degree reveal that a series of reasons including practicality, trumped prestige and flexibility of part-time programs,

Working adults pursuing part-time MBA programs (Panitz, 1995) expected their MBA experience to be a career enhancing action and wanted the institution chosen to provide this enhancement to a superior level. Accreditation organizations, such as the Association to Advance Collegiate Schools of Business (AACSB), offer schools the opportunity to meet criteria for excellence. The top four (4) expectations MBA students deemed important in an MBA program are: 1) Accreditation, 2) Quality of instruction, 3) Professors having business experience, and 4) Professors know theory.

It is interesting to note that the full-time graduate students had a top ranking selection different from the part-time working adult students (Richardson and Stacey, 1993). The rank order of this study for full-time students was: 1) Placement of graduate, 2) Academically challenging program, 3) Reputation of department faculty and 4) Departmental faculty/graduate student ratio.

"The wide range of results seen in the literature may be due to several factors. Student samples can range dramatically on their educational objective, economic level and socialization patterns. Other factors could include the academic field or preference of the students surveyed and the timing of the study," (Powers, 1988).

\section{RESEARCH QUESTION AND HYPOTHESES}

We wanted to know if the importance of the selection criteria remained relatively consistent for students entering the programs and students completing the programs. In other words, did the percentage of specific reasons for selecting SWU remain the same over time or differ as the students approached graduation? The survey was also used to collect data pertaining to the top four (4) objectives of AGS and to determine the criteria influencing selection of Southern Wesleyan University to earn a graduate degree in management/business administration.

The questionnaire was very simple and only asked for their cohort number and the following open-ended question: "Why did you choose to pursue a graduate degree (MSM/MBA) at Southern Wesleyan University?" The responses were open-ended. The questions did not ask for a rank ordering but rather a listing of reasons. Even though the tabulated data suggested a rank ordering of reasons, it more accurately represented the response frequency of each reason. We did, however, utilize the data to create a Pareto chart listing frequencies.

The data gathering procedures occurred during the first two courses in the SWU programs and were deposited in the "start" category (first two courses in the program). Data for the "completion" category were collected during either the last workshop or next to the last workshop (last two courses).

The hypotheses testing related to comparing the "start" and "completion" data gathered from the respondents. The general null hypothesis states there is no significant difference between reasons for choosing a graduate degree program (either the MSM or MBA) at Southern Wesleyan University from the "start" of the program or at the "completion" of the program. We utilized the first four (4) reasons for selection since they represented slightly over $50 \%$ of the total reasons.

The hypothesis testing involved two proportions. It was a two-tailed test: The confidence coefficient selected was .95 and the level of significance selected was 0.05 .

Assuming a normal curve for each of the responses and applying that $95 \%$ of the computed critical ratio $(z)$ values will be between -1.96 and +1.96 under the assumption that there was no significant difference between the proportions. The areas of rejection were 0.025 at the far right and far left of the normal curve.

\section{RESEARCH RESULTS AND DISCUSSIONS}

Hypothesis \# 1: There is no significant difference between "Fits my schedule" for choosing a graduate degree program (either the MSM or MBA) at Southern Wesleyan University at the "start" of the program or at the 
"completion" of the program. The alternative hypothesis states that there is a significant difference. The critical (z) value was calculated to be -0.26 ; therefore, accept the null hypothesis.

Hypothesis \# 2: There is no significant difference between "Job advancement/marketability" for choosing a graduate degree program (either the MSM or MBA) at Southern Wesleyan University at the "start" of the program or at the "completion" of the program. The alternative hypothesis states that there is a significant difference. The critical (z) value was calculated to be 1.15; therefore, accept the null hypothesis.

Hypothesis \# 3: There is no significant difference between "Received undergraduate degree from SWU" for choosing a graduate degree program (either the Master of Science in Management or Master of Business Administration) at Southern Wesleyan University at the "start" of the program or at the "completion" of the program. The alternative hypothesis states that there is a significant difference. The critical (z) value was calculated to be -0.71 ; therefore, accept the null hypothesis.

Hypothesis \# 4: There is no significant difference between "Christian perspective" for choosing a graduate degree program (MSM or MBA) at Southern Wesleyan University at the "start" of the program or at the "completion" of the program. The alternative hypothesis states that there is a significant difference. The critical (z) value was calculated to be -1.28 ; therefore, accept the null hypothesis.

When comparing the information presented in Table 1 to that of the University's AGS Masters' program objectives, the following comments are offered.

AGS Objective \# 1: “Offer a program leading to an Associate's, Bachelor's, or Master's degree to people whose occupation, family responsibilities, or personal preferences do not permit them to spend major blocks of time in residence on a campus." The reason "Fits my schedule" is ranked number one in both categories of the survey. At the start of the program $23 \%$ of the sample population ranked "Fits my schedule" the highest, and at the end of the program 22.4\% ranked this reason number one. The University's number one program objective is considered number one by the sample population both at the beginning of the program and at the end of the program.

AGS Objective \# 2: "Provide a degree program that requires mastery of learning outcomes at the academic level appropriate to students' degree goals." "Job advancement/ marketability" is ranked second in both categories of the survey. At the start of the program $16.1 \%$ of the sample population ranked "Job advancement/marketability" second highest, and at the end of the program $12 \%$ ranked this reason number two.

AGS Objective \# 3: "Provide students with a comprehensive, yet practical education through an intense curriculum that draws on resources, theories and knowledge of all relevant disciplines in order to enable the students to acquire skills in communication, information processing, analysis, syntheses and problem solving." "Learn more about management" is ranked number ten at the start of the program with $3.2 \%$ responding. At the end of the program with $4.1 \%$ responding, this reason was ranked number seven.

AGS Objective \# 4: "Facilitate an understanding of the importance of a dynamic social conscience and the application of Christian principles in a professional environment." "Christian perspective" is ranked number four at the start of the program with $7.4 \%$ responding, and at the end of the program "Christian Perspective" was ranked number three with $8.3 \%$ responding.

Working adults with college degrees are aware of the continuing changes in the business environment. Their undergraduate degrees have usually factored into their present employment opportunity. As their business experiences increase, it is quite natural to begin to give thought to the need for additional education/formal training to keep their knowledge attuned with new directions to problem solving. Actual work experience calls attention to the greater need to make daily decisions in their work. Always there is a consideration for additional studies to enhance earning power through job advancement recognition.

After concluding that one needs to plan for earning a graduate business degree, we wondered if the evening students pursuing an MBA or MSM degree at SWU had rethought their decision selection criteria when they 
reflected on their 18-month tenure with the SWU program. If they were given the chance to answer the question, "Why did you choose to pursue a graduate degree (MSM/MBA) at Southern Wesleyan University?" again, would they have a different set of selection criteria?

Table 1 - Student Ranking: Start and Completion Data

\begin{tabular}{|c|c|c|c|c|c|c|c|}
\hline \multicolumn{4}{|c|}{ Start } & \multicolumn{4}{|c|}{ Completion } \\
\hline $\begin{array}{l}\text { Rank } \\
\text { order }\end{array}$ & Quantity (n) & $\%$ & Reason & $\begin{array}{l}\text { Rank } \\
\text { order }\end{array}$ & Quantity (n) & $\%$ & Reason \\
\hline 1 & 50 & 23.0 & Fits my schedule & 1 & 54 & 22.4 & Fits my schedule \\
\hline 2 & 35 & 16.1 & $\begin{array}{l}\text { Job advancement/ } \\
\text { marketability }\end{array}$ & 2 & 29 & 12.0 & $\begin{array}{l}\text { Job advancement/ } \\
\text { marketability }\end{array}$ \\
\hline 3 & 19 & 8.8 & $\begin{array}{l}\text { Received undergraduate } \\
\text { degree from } S W U\end{array}$ & 3 & 24 & 10.0 & Christian perspective \\
\hline 4 & 16 & 7.4 & Christian perspective & 4 & 20 & 8.3 & $\begin{array}{l}\text { Received undergraduate } \\
\text { degree from } S W U\end{array}$ \\
\hline 4 & 16 & 7.4 & $\begin{array}{l}\text { Convenient to my home } \\
\& \text { work }\end{array}$ & 5 & 15 & 6.2 & 18 month schedule \\
\hline 4 & 16 & 7.4 & Personal goal & 6 & 13 & 5.4 & $\begin{array}{l}\text { Convenient to my home \& } \\
\text { work }\end{array}$ \\
\hline 7 & 14 & 6.5 & 18 month schedule & 7 & 10 & 4.1 & $\begin{array}{l}\text { Learn more about } \\
\text { management }\end{array}$ \\
\hline 8 & 12 & 5.5 & $\begin{array}{l}\text { Group/Team work/small } \\
\text { class size }\end{array}$ & 7 & 10 & 4.1 & Personal goal \\
\hline 9 & 10 & 4.6 & Cost was reasonable & 7 & 10 & 4.1 & $\begin{array}{l}\text { Quality of professors, } \\
\text { with real world } \\
\text { experience }\end{array}$ \\
\hline 10 & 7 & 3.2 & $\begin{array}{l}\text { Learn more about } \\
\text { management }\end{array}$ & 10 & 8 & 3.3 & $\begin{array}{l}\text { Group/Team work/small } \\
\text { class size }\end{array}$ \\
\hline 11 & 5 & 2.3 & $\begin{array}{l}\text { Quality of professors, } \\
\text { with real world } \\
\text { experience }\end{array}$ & 11 & 7 & 2.9 & $\begin{array}{l}\text { Excellent } \\
\text { reputation/structure }\end{array}$ \\
\hline 12 & 17 & 7.8 & "Other" & 12 & 41 & 17.2 & "Other" \\
\hline Total & 217 & \multicolumn{2}{|l|}{$100 \%$} & Total & 241 & \multicolumn{2}{|l|}{$100 \%$} \\
\hline \multicolumn{4}{|c|}{ Total Number of Students $=90$} & \multicolumn{4}{|c|}{ Total Number of Students $=94$} \\
\hline
\end{tabular}

The conclusions is that the differences in responses were insignificant, and we accepted the null hypotheses that there are no significant differences between responses at the "start" and "completion" portions of the graduate level programs. Therefore, the students were consistent in responding to the survey question. The responses and the knowledge of consistency can be used in marketing programs with a great deal of assurance.

When comparing the results of the survey to the four (4) general objectives of SWU, we find a very good connection and linkage between the University's objectives and the survey results.

As cited in the literature search, students selecting a university for full-time (traditional) undergraduate/graduate work have a list of criteria that includes: Academic reputation, Programs of study, Cost advantages, Recommendations of parents and Placement of graduate. The adults pursuing part-time (nontraditional) MBA/MSM in the beginning of the SWU program selected the rank order of: Fits my schedule, Job advancement/marketability, Received undergraduate degree from SWU, a Christian perspective, Convenient to my home and work, etc. These first five (5) reasons were listed by $70 \%$ of the respondents' responses.

\section{LIMITATIONS AND RECOMMENDATIONS}

The good news is that the new students coming into the program and those graduating are the types of students that the university has been recruiting to support its institutional culture and goals. We can say that the 
values of entering as well as graduating students, studied in this research, seem to be similar when it comes to their preferences and needs for choosing graduate business programs. What is also interesting is that the nearly two years of graduate schooling has not impacted the rankings of graduating students. Thus, it can be implied that the values of students tend to remain similar, at least, over a short period of time. Since a person's values drive his/her actions, these students would make the same choices if they had to do it over again. The consistency between the responses of entering and graduating students could also means that these students who are soon to be alumni are happy with their choice of school and program.

As with any study, there are some limitations to this research as well. Since the responses are limited to a small size ( $\mathrm{n}=184)$, the results cannot be generalized to other students or universities. Future researchers can involve more students and compare the results longitudinally over a five to ten year period. Since the entering students and graduating students were different groups studied during the same time period, the results could reflect other variables linked to the institution's culture and not necessarily the values and preferences of the students. Looking at more groups in different years can provide a control mechanism for institutional issues related to the university and their specific focus at a given time. Finally, since the students surveyed had already chosen this school, it might represent the similarities of values in their socialization or geographical upbringings. Perhaps students from other schools' MBA Programs can be included in future surveys to compare the results. Future studies can put more variables into the process to see where the students are coming from and whether location, ethnicity and/or gender actually make a difference in the rankings.

\section{CONCLUSION}

The students seem to have a strong expectation of a non-traditional, higher education program being flexible enough to meet the time demands of today's working professionals and affording job advancement and marketability in today's competitive workplace. In addition, they recognized the distinctiveness of the academic institution utilized in this study that affords both undergraduate and graduate degrees with a Christian perspective. At the same time, while it is easy to establish a rank ordering of information regarding the selection of a particular academic institution, the final decision is most probably an amalgamation of inputs. Further studies should be pursued regarding other institutions of higher learning to research the importance of the distinctiveness in choosing a school for the pursuit of a graduate degree, and there could be an opportunity to explore demographics as determining factors.

\section{AUTHOR INFORMATION}

Dr. Ronald L. Snyder is an Associate Professor in Business for graduate level programs at Southern Wesleyan University and an Adjunct Professor of Business at Nova Southeastern University. He earned his MBA from New York Institute of Technology and his Doctor of Business Administration from Nova Southeastern University. Dr. Snyder has a wide background of management experience in diverse manufacturing industries. He has also worked as a consultant specializing in organizational performance improvement. His teaching and research interests include operations management, strategic management, marketing and organizational behavior. $\mathrm{He}$ is a member of the Production and Operations Management Society (POMS).

Dr. Lee E. Kizer is an Associate Professor of Business at Southern Wesleyan University and an Adjunct Professor of Business at Nova Southeastern University. He earned his MBA from the University of Arkansas and his Doctor of Science in Human Resource Management from Nova Southeastern University. His publications include cross cultural case studies as well as research in employee performance as a result of training. Dr. Kizer's research interests include topics in the area of employee motivation, employee retention, compensation and job analysis and design. He is currently working on a research project involving training instructors in cross cultural settings in the Bahamas and employee retention in the plastics industry in South Carolina. As a former Special Agent for the Federal Bureau of Investigation (FBI), he continues to perform security contract work for the federal government with the Department of Energy, the Department of Defense and the Department of Justice. He is a member of the Society of Human Resource Management (SHRM). 
Dr. Bahaudin G. Mujtaba is Department Chair and an Associate Professor of Management, Human Resources Management, and International Management at Nova Southeastern University's H. Wayne Huizenga School of Business and Entrepreneurship. For the past twenty-two years, Bahaudin has served as manager, trainer and management development specialist in the corporate world as well as a director, department chair and faculty member in academia. His areas of research are management, leadership, customer service, training, diversity management, and cross-cultural management.

Dr. Nile M. Khanfar is an assistant professor at Nova Southeastern University College of Pharmacy in West Palm Beach campus. He received his Ph.D. in Pharmacy Administration from the University of Louisiana at Monroe Dr. Khanfar has presented several podium and poster presentations at national and international Business and Pharmacy conferences. His research interest includes topics in the fields of marketing, management and healthcare. His work has been published in several peer-reviewed business and pharmacy journals.

\section{REFERENCES}

1. AGS Student Handbook, Southern Wesleyan University, 2005, p 4.

2. Bowers, T. A., \& Pugh, R.C. (1973). Factors underlying college choice by students and parents. Journal of College Student Personnel, 14, 220-224.

3. Broekemier, G.M. \& Seshadri, S. (1999). Differences in College Choice Criteria Between Deciding Students and Their Parents. Journal of Marketing for Higher Education, 1999 v9 i3 p 1-13.

4. Broekemier, G. M. (2002). A Comparison of Two-Year and Four-Year Adult Students: Motivations to Attend College and the Importance of Choice Criteria. Journal of Marketing for Higher Education v12 i1 p 31- 48.

5. Carrel, A. E., \& Schoenbachler, D. D. (2001). Marketing Executive MBA Programs: A Comparison of Student and Sponsoring Organization Decision Considerations. Journal of Marketing for Higher Education, v 11 i1 p 21-38.

6. Chui, R.K. \& Stembridge, A. (1999). How do full-time employees select part-time MBA programs in Hong Kong? SAM advance Management Journal, Spring 1999 v64 i2 p 34(6).

7. Clinton, R. J. (1989). Factors That Influence the College Prospect's Choice of Schools: Methodology, Analysis and Marketing Implications of a Recent Study. Journal of Marketing for Higher Education v2 i2 p 31-45.

8. $\quad$ Couch, Daryl (2005). MSM/MBA 2005 SWU Student Data.

9. Fieser, E. (2002). Interest in MBA Programs surges throughout Maryland. Daily Record (Baltimore, MD), April 27, 2002 pNA.

10. Kenney, M. and Mujtaba, B. G. (2008). Entrepreneurs entering the higher education market to make a difference: The Kenney College of Entrepreneurship. Journal of Business Case Studies; Vol. 4, Num. 1; pages $99-112$.

11. Kerr, J. (1995). Part-time study gains popularity. Hong Kong; South China Morning Post, 194.

12. Luker, A., Bowers, M. R., \& Powers, T. L. (1989). Factors Influencing Pursuit of the MBA Degree: A Student and Employer Perspective. Journal of Marketing for Higher Education, V2 i2 p 87 - 96.

13. Mujtaba, B. G. (December 2007). Understanding the needs and wants of virtual students: Online MBA Program at the H. Wayne Huizenga School of Business and Entrepreneurship of Nova Southeastern University. TechTrends, Vol. 51, No. 6; pages 46-51. Retrieved on July 14, 2008 from: http://www.redorbit.com/news/education/1164805/understanding the needs_and_wants_of_virtual_studen ts/index.html.

14. Mujtaba, B. G. (2007). Religious diversity in the workplace: accommodating the needs of employees. Smart Business: the Management Journal for Corporate Growth. Vol. 4, No. 4, page 18. Retrieved on July 17, 2008 from: http://www.sbnonline.com/National/Article.aspx?CID=13542.

15. Mujtaba, B. G., McAtavey, J. (2006). Performance Assessment and Comparison of Learning in International Education: American versus Jamaican Students' Learning Outcomes. The College Teaching Methods \& Styles Journal, Vol. 2, Num. 3. Pages 33-43.

16. MacErlean, N. (1993). Master Classes. Accountancy, v 111 i1195 p 29-34.

17. Oldham, C. (2000). Part-time MBA programs allow women to balance school, family. The Dallas Morning News (via Knight-Ridder/Tribune News service), Oct 31, 2000 pNA. 
18. Panitz, E. (1995). Part-Time MBA Students' Expectations of Their academic Experience. Journal of Marketing for Higher Education v6 i1 p 87 - 95.

19. Powers, T. L. (1988). The Consumer Perspective on Business School Evaluation. Journal of Marketing for Higher education, v1 i1 p $109-131$.

20. Richardson, L. D. \& Stacey, E. C. (1993). Key Attributes Affecting Students' Applications to MBA Programs: Public vs. Private Institutions. Journal of Marketing for Higher Education v4 i1/2 p 235- 249.

21. Sevier, R. A. (1987). How students choose a college. Currents, December 1987, v12 i10 p 46-52.

22. Snyder, R. L.; Kizer, L. E.; Mujtaba, B. G.; and Khanfar, N. M. (2008). Comparing and Managing the Relative Importance and Ranking of Reasons for Selecting the Masters' of Business Administration Program. Global Academy of Business \& Economic Research Proceedings; September 18, 2008; Orlando, Florida.

23. Webb, M. S., \& Allen L. C. (1994). Graduate Business Students: Factors that Differentiate Diverse Markets' Matriculating Decisions. Journal of Marketing for Higher Education v5 i1 p 87-107.

24. Yeaple, R. (1994, August 6). The MBA cost-benefit analysis. Economist, 332(7875), 58. 
NOTES 